\title{
Reduction of the Heterocyclic Amines in Grilled Beef Patties through the Combination of Thermal Food Processing Techniques without Destroying the Grilling Quality Characteristics
}

\author{
Wei Wang ${ }^{1}$, Lu Dong ${ }^{2}$, Yan Zhang ${ }^{2}$, Huaning $\mathrm{Yu}^{3, *}$ and Shuo Wang ${ }^{1,2, *}$ \\ 1 Key Laboratory of Food Nutrition and Safety, Ministry of Education of China, Tianjin University of Science \\ and Technology, Tianjin 300457, China; weilianyi@163.com \\ 2 Tianjin Key Laboratory of Food Science and Health, School of Medicine, Nankai University, \\ Tianjin 300071, China; donglu@nankai.edu.cn (L.D.); yzhang@nankai.edu.cn (Y.Z.) \\ 3 Midea Group Guangdong Midea Kitchen Appliances Manufacturing Co., Ltd., Foshan 528000, China \\ * Correspondence: yuhuaning1981@126.com (H.Y.); wangshuo@nankai.edu.cn (S.W.); \\ Tel.: +86-18149701201 (H.Y.); +86-22-85358445 (S.W.)
}

Citation: Wang, W.; Dong, L.; Zhang, Y.; Yu, H.; Wang, S. Reduction of the Heterocyclic Amines in Grilled Beef Patties through the Combination of Thermal Food Processing Techniques without Destroying the Grilling Quality Characteristics. Foods 2021, 10, 1490. https://doi.org/10.3390/ foods 10071490

Academic Editors: Maria João dos Ramos Fraqueza and Annalisa Tassoni

Received: 12 May 2021

Accepted: 25 June 2021

Published: 27 June 2021

Publisher's Note: MDPI stays neutral with regard to jurisdictional claims in published maps and institutional affiliations.

Copyright: (c) 2021 by the authors. Licensee MDPI, Basel, Switzerland. This article is an open access article distributed under the terms and conditions of the Creative Commons Attribution (CC BY) license (https:// creativecommons.org/licenses/by/ $4.0 /)$.

\begin{abstract}
In order to reduce the formation of heterocyclic amines in grilled beef patties without destroying their unique quality characteristics, the effects of different thermal processes, including charcoal grilling, infrared grilling, superheated steam roasting and microwave heating, on the production of heterocyclic amines in beef patties and grilling quality characteristics were systematically analyzed. The results showed that infrared grilling can significantly $(p<0.05)$ reduce the content of heterocyclic amines in grilled patties, and the combination of microwave heating or superheated steam roasting with infrared grilling could further reduce the content of heterocyclic amines, with a maximum reduction ratio of $44.48 \%$. While subtle differences may exist in infrared grilled patties with/without superheated steam roasting or microwave heating, a slight change will not affect the overall quality characteristics of grilled patties. The combined thermal processing will not visually affect the color of the grilled patties. Correlation analysis and regression analysis showed that the reduction in heterocyclic amines caused by microwave heating and superheated steam roasting are related to the moisture content and lipid oxidation of grilled patties, respectively. Using combined thermal processes to reduce the formation of heterocyclic amines is advisable.
\end{abstract}

Keywords: heterocyclic amines; thermal food process; reduction; beef patties; quality

\section{Introduction}

Carcinogenic heterocyclic amines (HAs) are formed in protein-rich foodstuffs (e.g., meat) during thermal processes such as grilling. HAs are classified into two major types: thermic HAs (amino-imidazo-azaarenes (AIAs)) and pyrolytic HAs (amino carbolines). Thermic HAs (such as 8-MeIQx (2-amino-3,8-dimethylimidazo [4,5- $f$ ]quinoxaline), 4,8DiMeIQX (2-amino-3,4,8-trimethylimidazo[4,5-f]quinoxaline), and PhIP (2-amino-1-methyl6-phenyl-imidazo[4,5-b]pyridine)) are commonly formed by amino acids, creatinine (creatine) and glucose due to the Maillard reaction, while pyrolytic HAs (such as Norharman (9 H-pyrido[4,3-b]indole) and Harman (1-methyl-9 H-pyrido[4,3-b]indole)) are produced by the pyrolysis of proteins [1]. The formation of HAs in food was influenced by the type, temperature and duration of the thermal processes [2].

The formation of HAs by adjusting thermal processes or process conditions and adding with antioxidant compounds can be mitigated [3]. Adding active substances to foodstuffs has attracted extensive interest because of its convenience. However, it is undeniable that the thermal instability of the active substance limits its effect [4], and may introduce new, 
potentially harmful compounds which were formed by complex reactions between the new compounds and the composition of meat $[5,6]$.

Charcoal grilling (CG) is a traditional cooking method that can produce HAs, and the scorching phenomenon of CG affects people's appetite due to uneven heating [7]. In terms of the quality of the products, infrared grilling (IG) is an effective technology due to its uniform and faster heating [8]. Compared with IG, microwave heating is more efficient because it can penetrate to deeper parts of the food, while almost all the energy of infrared radiation is absorbed by the surface of the food, and slow heat conduction needs to enter the food for infrared radiation [9]. Although the microwave has been widely used in food processing, it has several disadvantages. One is that many foods cannot trigger a browning reaction through microwaves, because the temperature of the food surface is lower than the inside, but it can be used in combination with IG to heat the food surface to a high enough temperature to cause a browning reaction. The second is that the cooked meat loses more moisture and the texture of the meat is too dry due to the rapid heating, which can be improved by combining this with superheated steam roasting (SHS). SHS is a modern thermal process that can increase the heat penetration rate in meat products when the saturated steam continues to be heated at a given pressure, since the temperature of the steam is higher than the saturation temperature [10].

When studying the thermal food processing techniques, researchers like to compare techniques in isolation to study the production of HAs [11-13]. The bottleneck of the research on the influence of processing methods on HAs is that few people have combined several processing methods into the same thermal processing to reduce and control the production of HAs. Furthermore, research on the influence of the microwave on the content of HAs has focused on the microwave as a pretreatment method [14,15], and the effect of microwave cooking on the formation of HAs is still unclear. In a study by Oz et al. [13], microwave cooking could reduce the formation of HAs in fried chicken meat products, whereas another study found higher mutagenic activity in meat cooked by the microwave $[9,16]$. Whether the microwave can reduce HAs remains to be determined. Moreover, there is not much research on the influence of SHS on the content of HAs [17,18], and explorations of the possible causes connected with other substrates in food are rare. Our goal was to reduce the production of carcinogenic HAs by a combination of thermal processing techniques, and to offer preliminary explorations for this. In this process, we also ensured the quality characteristics of the patties.

To realize the reduction in the formation of HAs, and maintain the original grilling characteristics of grilled patties, the effects of different thermal processes with different heating principles and characteristics and their combinations on HAs formation, as well as the quality characteristics (texture, color), moisture content and lipid oxidation (thiobarbituric acid (TBA) value) of beef patties were investigated. Additionally, the correlation and regression analyses between $\mathrm{HAs}$, moisture content and the TBA value of grilled patties were analyzed to explore the involved mechanisms, which will provide a new strategy for the mitigation of unhealthy compounds and improve the safety and quality of thermal processed foods.

\section{Materials and Methods}

\subsection{Materials and Reagents}

Lean shoulder blade beef meat was obtained from the local supermarket (Tianjin, China). All analytical grade chemicals including ammonia, hydrochloric acid, sodium hydroxide, magnesium sulfate, trichloroacetic acid, chloroform, ethylene diamine tetraacetic acid (EDTA) and acetate were obtained from Toronto Research Chemicals Co. CAN. The HPLC-grade solvents including methanol and acetonitrile, and 11 HAs standards (>99\% purity) including MeIQ (2-Amino-3,4-dimethylimidazo[4,5- $f$ ]quinoline), IQx (2-amino-3methylimidazo[4,5-f]-quinoxaline), 8-MeIQx, 4,8-DiMeIQx, 7,8-DiMeIQx (2-amino-3,7,8trimethylimidazo[4,5-f]quinoxaline), PhIP, Harman, Norharman, Trp-P-2 (3-Amino-1methyl-5 H-pyrido[4,3-b]indole), A $\alpha \mathrm{C}$ (2-Amino-9 H-pyrido[2,3-b]indol) and MeA $\alpha \mathrm{C}$ 
(2-Amino-3-methyl-9 H-pyrido[2,3-b]indol) were purchased from Sigma Aldrich Co. USA. Oasis ${ }^{\circledR}$ MCX 3 cc (extraction column) and ACQUITY UPLC ${ }^{\circledR}$ BEH C18 $(2.1 \mathrm{~mm} \times 100 \mathrm{~mm}$, $1.7 \mu \mathrm{m}$ ) were procured from Waters Corporation Co. USA.

\subsection{Sample Preparation}

The lean meat was thawed over-night $\left(5^{\circ} \mathrm{C}\right)$ and then chopped using a mechanical mincer. No salt and other spices were applied to the minced meat. Every $100 \pm 1 \mathrm{~g}$ of meat was made into each patties sample through the mold (100 $\mathrm{mm}$ dia. $\times 15 \mathrm{~mm}$ thick). Next, 66 beef patties samples were prepared for each batch and three batches of beef patties samples were grilled in total.

\subsection{Cooking of Patties by Different Thermal Processes}

Beef patties were grilled according to five grilling processes (CG (charcoal grilling), IG (infrared grilling), IG-SHS (superheated steam roasting)-IG, IG-microwave-IG, IGmicrowave-SHS-IG). Three replicates were performed for each thermal process. For CG, the patties were grilled over charcoal which was placed in the bottom of the charbroiler (CF-E112013, e-Rover Ltd., Ningbo, China). In addition, the grilled beef patties preparation oven is an internal modification equipment in the laboratory, which integrates the three functions of IG, SHS and microwave heating. The equipment parameters are: the size of the oven cavity is $380 \mathrm{~mm} \times 320 \mathrm{~mm} \times 200 \mathrm{~mm}$; the grilling temperature range is $0-230{ }^{\circ} \mathrm{C}$; the microwave output power range is $200-1000 \mathrm{~W}$; the superheated steam roasting temperature is $100{ }^{\circ} \mathrm{C}$. For combined thermal processes, the patties were grilled for $8 \mathrm{~min}$ with IG first to ensure the grilled flavor of the patties. The 8-min grilling temperature in the first step was consistent with the grilling temperature used in the subsequent grilling process. In Tables 1-3, the grilling temperature of each combined thermal process was marked. The grilling tray inside the oven is grid-shaped so that patties can be grilled on both sides at the same time. Three grilling temperatures $\left(180^{\circ} \mathrm{C}, 200{ }^{\circ} \mathrm{C}\right.$ and $\left.220^{\circ} \mathrm{C}\right)$, two values of microwave power $(1000 \mathrm{~W}, 500 \mathrm{~W})$, three values of microwave time (10 s, $30 \mathrm{~s}$ and $60 \mathrm{~s})$ and three SHS times ( 3,4 and $5 \mathrm{~min}$ ) were studied. All the thermal processes were ended when patties reached an internal temperature of $75^{\circ} \mathrm{C}$, which was monitored using a thermocouple thermometer (4 CH-20 CH, GND Ltd., Shanghai, China).

Table 1. Thermal process of "IG-SHS-IG". "IG" means infrared grilling, "SHS" means superheated steam roasting.

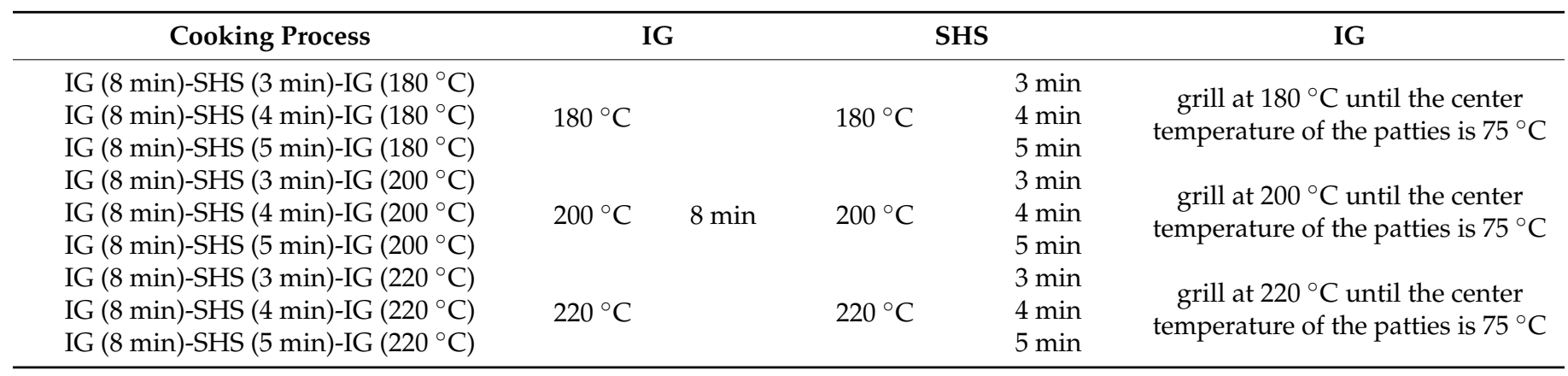

Table 2. Thermal process of "IG-microwave-IG". "IG" means infrared grilling.

\begin{tabular}{|c|c|c|c|c|}
\hline Cooking Process & IG & \multicolumn{2}{|c|}{ Microwave Heating } & IG \\
\hline $\begin{array}{l}\text { IG (8 min)-microwave (1000 w } 10 \mathrm{~s})-\mathrm{IG}\left(200^{\circ} \mathrm{C}\right) \\
\text { IG (8 min)-microwave }(500 \mathrm{w} 10 \mathrm{~s})-\mathrm{IG}\left(200^{\circ} \mathrm{C}\right) \\
\text { IG }(8 \mathrm{~min}) \text {-microwave }(500 \mathrm{w} 30 \mathrm{~s})-\mathrm{IG}\left(200^{\circ} \mathrm{C}\right) \\
\text { IG (8 min)-microwave }(500 \mathrm{w} 60 \mathrm{~s})-\mathrm{IG}\left(200^{\circ} \mathrm{C}\right)\end{array}$ & $200^{\circ} \mathrm{C}, 8 \mathrm{~min}$ & $1000 \mathrm{~W}$ & $\begin{array}{l}10 s \\
10 s \\
30 s \\
60 s\end{array}$ & $\begin{array}{l}\text { grill at } 200{ }^{\circ} \mathrm{C} \text { until the } \\
\text { center temperature of } \\
\text { the patties is } 75^{\circ} \mathrm{C}\end{array}$ \\
\hline
\end{tabular}


Table 3. Thermal process of "IG-microwave-SHS-IG". "IG" means infrared grilling, "SHS" means superheated steam roasting.

\begin{tabular}{|c|c|c|c|c|c|}
\hline Cooking Process & IG & \multicolumn{2}{|c|}{$\begin{array}{l}\text { Microwave } \\
\text { Heating }\end{array}$} & SHS & IG \\
\hline $\begin{array}{c}\text { IG (8 min)-microwave }(1000 \mathrm{w} 10 \mathrm{~s}) \text {-SHS } \\
(4 \mathrm{~min})-\mathrm{IG}\left(200^{\circ} \mathrm{C}\right)\end{array}$ & \multirow{4}{*}{$200^{\circ} \mathrm{C}, 8 \mathrm{~min}$} & $1000 \mathrm{~W}$ & $10 \mathrm{~s}$ & \multirow{4}{*}{$200{ }^{\circ} \mathrm{C}, 4 \mathrm{~min}$} & \multirow{4}{*}{$\begin{array}{l}\text { grill at } 200{ }^{\circ} \mathrm{C} \text { until the } \\
\text { center temperature of the } \\
\text { patties is } 75^{\circ} \mathrm{C}\end{array}$} \\
\hline $\begin{array}{c}\text { IG (8 min)-microwave }(500 \mathrm{w} 10 \mathrm{~s}) \text {-SHS } \\
(4 \mathrm{~min}) \text {-IG }\left(200^{\circ} \mathrm{C}\right)\end{array}$ & & & $10 \mathrm{~s}$ & & \\
\hline $\begin{array}{c}\mathrm{IG}(8 \mathrm{~min})-\mathrm{microwave}(500 \mathrm{w} 30 \mathrm{~s})-\mathrm{SHS} \\
(4 \mathrm{~min})-\mathrm{IG}\left(200^{\circ} \mathrm{C}\right)\end{array}$ & & $500 \mathrm{~W}$ & $30 \mathrm{~s}$ & & \\
\hline $\begin{array}{c}\text { IG (8 min)-microwave }(500 \mathrm{w} 60 \mathrm{~s}) \text {-SHS } \\
(4 \mathrm{~min})-\mathrm{IG}\left(200^{\circ} \mathrm{C}\right)\end{array}$ & & & $60 \mathrm{~s}$ & & \\
\hline
\end{tabular}

\subsection{Quantification of $H A s$}

To obtain good recovery and reproducibility, HAs were purified on Oasis MCX cartridge (Polypropylene, $3 \mathrm{cc}, 60 \mathrm{mg}$ ), then analyzed by UPLC-MS/MS (ACQUITY / Xevo TQ-S micro, Waters, Milford, MA, USA) method. In brief, $1 \mathrm{~g}$ of cooked meat sample was homogenized in a $10 \mathrm{~mL} \mathrm{NaOH}$ solution $(0.1 \mathrm{M})$ for $5 \mathrm{~min}$. Then, $10 \mathrm{~mL}$ of acetonitrile and vortex was added for $1 \mathrm{~min}$, followed by the addition of $6 \mathrm{~g} \mathrm{MgSO}_{4}$ and $1.5 \mathrm{~g}$ sodium acetate and vortex for $5 \mathrm{~min}$. Finally, this was centrifuged at $5000 \mathrm{r} / \mathrm{min}$ for $5 \mathrm{~min}$, and the supernatant was collected for solid phase extraction. The MCX cartridge was activated with $3 \mathrm{~mL}$ methanol and $3 \mathrm{~mL} 0.01 \mathrm{M}$ hydrochloric acid solution, and the collected supernatant was loaded on the activated MCX column; then, $3 \mathrm{~mL} 2 \%$ formic acid water, $9 \mathrm{~mL}$ deionized water and $3 \mathrm{~mL}$ methanol were used to wash the impurities. A total of $3 \mathrm{~mL}$ of mixture of methanol and ammonia $(9: 1, v / v)$ was used as the eluent, then the eluent containing the HAs was collected and dried using a nitrogen gas stream, before being reconstituted with $1 \mathrm{~mL}$ of methanol. It was filtered through a $0.22 \mu \mathrm{m}$ organic microporous filter membrane into a sample vial for UPLC-MS/MS analysis.

An ACQUITY UPLC BEH C18 column was used for the separation. The column temperature was set to $45^{\circ} \mathrm{C}$. The mobile phase, $\mathrm{A}$ and $\mathrm{B}$, was made up of ultrapure water and acetonitrile. The gradient programm was: $0-0.5 \mathrm{~min}, 90 \% \mathrm{~A} ; 0.5-10 \mathrm{~min}, 50-90 \% \mathrm{~A}$; 10-10.1 min, 50-90\% A; 10-15 min, 90\% A. An optimal baseline separation was achieved at a flow rate of $0.5 \mathrm{~mL} / \mathrm{min}$. ESI was performed in positive-ion mode; MRM mode was used for MS/MS detection. The optimal ionization source working parameters were as follows: nebulizer pressure, $40 \mathrm{psi}$; and capillary voltage, $900 \mathrm{~V}$. The drying gas flow rate and temperature were $800 \mathrm{~L} / \mathrm{Hr}$ and $400{ }^{\circ} \mathrm{C}$, the cone gas flow rate was $60 \mathrm{~L} / \mathrm{Hr}$, and the ion source temperature was $150^{\circ} \mathrm{C}$. The limits of detection (LODs), as well as the limits of quantitation (LOQs) and recovery of UPLC-MS/MS, are given in Supplementary Table S1.

\subsection{Moisture Content Analysis}

The moisture content of grilled patties was measured according to the China National Standard method (GB5009.3, 2016).

\subsection{Determination of TBA Value}

The TBA values were determined by the Method of Hai et al. [19]. A total of $50 \mathrm{~mL}$ of $7.5 \%$ trichloroacetic acid (containing $0.1 \%$ EDTA) was added to $10 \mathrm{~g}$ of the homogenized meat sample and shaken for $30 \mathrm{~min}$. Thereafter, the preparation was filtered twice with filter paper, and $5 \mathrm{~mL}$ of the supernatant was treated with $5 \mathrm{~mL}$ of $0.02 \mathrm{~mol} / \mathrm{L}$ TBA solution, incubated in a $95^{\circ} \mathrm{C}$ water bath for $50 \mathrm{~min}$, cooled to room temperature and centrifuged for $5 \mathrm{~min}(10,000 \mathrm{r} / \mathrm{min})$. The supernatant obtained was treated with $5 \mathrm{~mL}$ of chloroform and centrifuged for $5 \mathrm{~min}(10,000 \mathrm{r} / \mathrm{min})$. Finally, the supernatant underwent colorimetric analysis at 532 and $600 \mathrm{~nm}$ (Evolution 350, Thermo Fisher, Waltham, MA, USA). The absorbance was recorded and a blank test was performed. The results are expressed as milligrams of MDA per kilogram of meat (mg MDA/Kg). 


\subsection{Color Analysis}

Color parameters were measured and the values were recorded as three parameters of lightness $\left(\mathrm{L}^{*}\right)$, redness $\left(\mathrm{a}^{*}\right)$, and yellowness $\left(\mathrm{b}^{*}\right)$. The surface of the patties was randomly tested on by a chroma meter (CR-210, Minolta Ltd., Tokyo, Japan).

\subsection{Texture Profile Analysis}

The beef patties were cut into cubes $(1 \mathrm{~cm} \times 2 \mathrm{~cm} \times 2 \mathrm{~cm})$ and tested with a Texture Analyzer (TA-XT2 i, SMS Ltd., London, UK). Three cubes $(1 \mathrm{~cm} \times 2 \mathrm{~cm} \times 2 \mathrm{~cm})$ were taken from each sample, and nine cubes were totally taken from three parallel samples of each thermal treatment for determination. Samples were compressed to $30 \%$ of their original height by a cylindrical probe with a $3 \mathrm{~cm}$ diameter and $5 \mathrm{~mm} / \mathrm{s}$ speed. The parameters of hardness, springiness, cohesiveness, gumminess, chewiness and resilience were recorded.

\subsection{Statistical Analysis}

The data are expressed as the means \pm standard errors. SPSS (v. 24.0) was used for difference analysis by Duncan test and correlation analysis by Two-tail test. Origin Pro (v. 2019) was used for drawing figures.

\section{Results and Discussion}

\subsection{Effects of Different Thermal Processes on the Production of HAs in Grilled Beef Patties}

The effect of different thermal processes on the production of HAs in grilled beef patties was shown in Table 4 . The overall amount of HAs in charcoal grilled beef patties was $1.093 \mu \mathrm{g} / \mathrm{kg}$, which was higher in HAs content than patties grilled in the oven due to the production of thermic HAs (AIAs, about 55\%). For pyrolytic HAs, only Harman and Norharman were detected, as Felton et al. [20] believe that although Harman and Norharman can be formed, other pyrolytic HAs are basically undetectable in processed meat products. For thermic HAs, the content of PhIP, 8-MeIQX and 4,8-DiMeIQX were under the limit of detection in patties grilled in the oven. This finding is the same as the study by Polak et al. [21], who believe that most HAs are formed rapidly after heating, and degrade after reaching the highest level. Since the surface of patties is in contact with the highest temperature, HAs are easily produced on the surface of patties. As a type of polar HAs, AIAs can diffuse into the inside of patties, where the temperature is much lower, which can prevent self-decomposition by heat. The patties grilled by CG were exposed to charcoal fire and resulted in a higher conductive heat transfer and the shortest thermal processing time (The cooking times of the thermal processes are given in Supplementary Table S2). The relatively short thermal processing time of CG was not sufficient for AIAs to undergo thermal decomposition, so that part of the AIAs remained in the patties.

HAs produced by IG-SHS-IG patties were fewer than those produced by IG patties, which is consistent with the study by Suleman et al. [22]. The three superheated steam times added when the grilling temperature is $200{ }^{\circ} \mathrm{C}$ can significantly reduce the total amount of HAs; the inhibition rate of total HAs reaches $44.48 \%$ when the superheated steam time is $4 \mathrm{~min}$, which is the most effective process. Pathare and Roskilly [23] consider that SHS can reduce the surface temperature of the product and distribute heat evenly, thereby reducing the amount of HAs.

Similarly, HAs produced by IG-microwave-IG patties were lower $(p<0.05)$ than that produced by IG $\left(200^{\circ} \mathrm{C}\right)$ patties. Among the four time and power combinations, the total HAs reduction was as high as $11.49 \%(500 \mathrm{~W} 10 \mathrm{~s})$ to $44.48 \%$ (1000 W $10 \mathrm{~s})$. The amount of HAs decreased with the extension of microwave time and a decrease in microwave power. Furthermore, the successive addition of microwave and SHS will also reduce the amount of HAs. However, in terms of the inhibition of HAs, the continuous use of the microwave and SHS in one process was not as effective as adding microwave or SHS alone to IG. Compared with the $0.377 \pm 0.046 \mu \mathrm{g} / \mathrm{kg}$ HAs produced by IG-SHS $(4 \mathrm{~min})-\mathrm{IG}\left(200{ }^{\circ} \mathrm{C}\right)$ patties, HAs produced by IG-microwave-SHS $(4 \mathrm{~min})-\mathrm{IG}\left(200^{\circ} \mathrm{C}\right)$ patties was increased. 
The combination of microwave and SHS was not synergistic in inhibiting the production of HAs perhaps due to different inhibition reasons.

Table 4. Effects of different thermal processes on the production of HAs in grilled beef patties.

\begin{tabular}{|c|c|c|c|c|c|c|}
\hline \multirow[t]{2}{*}{ Cooking Process } & \multicolumn{5}{|c|}{ Types of HAs $(\mu \mathrm{g} / \mathrm{kg})$} & \multirow{2}{*}{$\begin{array}{l}\text { Total HAs } \\
(\mu \mathrm{g} / \mathrm{kg})\end{array}$} \\
\hline & 8-MeIQX & Norharman & $\begin{array}{c}4,8- \\
\text { DiMeIQX }\end{array}$ & Harman & PhIP & \\
\hline CG & $0.320 \pm 0.061$ & $0.242 \pm 0.040$ & $0.118 \pm 0.020$ & $0.247 \pm 0.014$ & $0.166 \pm 0.010$ & $1.093 \pm 0.090$ \\
\hline IG $\left(180^{\circ} \mathrm{C}\right)$ & ND & $0.355 \pm 0.052^{\mathrm{cd}}$ & ND & $0.088 \pm 0.011 \mathrm{bc}$ & ND & $0.443 \pm 0.061^{\mathrm{cd}}$ \\
\hline IG $\left(200^{\circ} \mathrm{C}\right)$ & ND & $0.544 \pm 0.013^{\mathrm{aAx}}$ & ND & $0.136 \pm 0.036^{\mathrm{bcAx}}$ & ND & $0.679 \pm 0.048^{\mathrm{abAx}}$ \\
\hline IG $\left(220^{\circ} \mathrm{C}\right)$ & ND & $0.501 \pm 0.15^{\mathrm{ab}}$ & ND & $0.235 \pm 0.12^{\mathrm{a}}$ & ND & $0.736 \pm 0.27^{\mathrm{a}}$ \\
\hline IG (8 min)-SHS (3 min)-IG $\left(180^{\circ} \mathrm{C}\right)$ & ND & $0.297 \pm 0.033^{\mathrm{d}}$ & ND & $0.094 \pm 0.016^{\mathrm{bcA}}$ & ND & $0.261 \pm 0.23^{\mathrm{d}}$ \\
\hline IG (8 min)-SHS (3 min)-IG $\left(200^{\circ} \mathrm{C}\right)$ & ND & $0.332 \pm 0.028^{\mathrm{cd}}$ & ND & $0.096 \pm 0.021 \mathrm{bc}$ & ND & $0.428 \pm 0.042^{\mathrm{cd}}$ \\
\hline $\mathrm{IG}(8 \mathrm{~min})-\mathrm{SHS}(3 \mathrm{~min})-\mathrm{IG}\left(220^{\circ} \mathrm{C}\right)$ & ND & $0.335 \pm 0.072^{\mathrm{cd}}$ & ND & $0.097 \pm 0.036^{\mathrm{bc}}$ & ND & $0.432 \pm 0.11^{\mathrm{cd}}$ \\
\hline $\mathrm{IG}(8 \mathrm{~min})-\mathrm{SHS}(4 \mathrm{~min})-\mathrm{IG}\left(180^{\circ} \mathrm{C}\right)$ & ND & $0.331 \pm 0.039 \mathrm{~cd}$ & ND & $0.075 \pm 0.003^{c}$ & ND & $0.406 \pm 0.041^{\mathrm{cd}}$ \\
\hline IG (8 min)-SHS (4 min)-IG $\left(200^{\circ} \mathrm{C}\right)$ & ND & $0.300 \pm 0.024^{\mathrm{d}}$ & ND & $0.077 \pm 0.03^{c}$ & ND & $0.377 \pm 0.046^{\mathrm{d}}$ \\
\hline $\mathrm{IG}(8 \mathrm{~min})-\mathrm{SHS}(4 \mathrm{~min})-\mathrm{IG}\left(220^{\circ} \mathrm{C}\right)$ & ND & $0.418 \pm 0.020^{b c}$ & ND & $0.121 \pm 0.021 \mathrm{bc}$ & ND & $0.539 \pm 0.041 \mathrm{bcd}$ \\
\hline IG (8 min)-SHS (5 min)-IG $\left(180^{\circ} \mathrm{C}\right)$ & ND & $0.269 \pm 0.021^{\mathrm{d}}$ & ND & $0.093 \pm 0.015^{b c}$ & ND & $0.362 \pm 0.036^{\mathrm{d}}$ \\
\hline $\mathrm{IG}(8 \mathrm{~min})-\mathrm{SHS}(5 \mathrm{~min})-\mathrm{IG}\left(200^{\circ} \mathrm{C}\right)$ & ND & $0.364 \pm 0.067^{\mathrm{cd}}$ & ND & $0.117 \pm 0.054^{b c}$ & ND & $0.481 \pm 0.12^{\mathrm{cd}}$ \\
\hline $\mathrm{IG}(8 \mathrm{~min})-\mathrm{SHS}(5 \mathrm{~min})-\mathrm{IG}\left(220^{\circ} \mathrm{C}\right)$ & ND & $0.422 \pm 0.028^{b c}$ & ND & $0.178 \pm 0.083^{\mathrm{ab}}$ & ND & $0.600 \pm 0.11^{\mathrm{abc}}$ \\
\hline $\begin{array}{c}\mathrm{IG}(8 \mathrm{~min}) \text {-microwave }(1000 \mathrm{w} 10 \mathrm{~s})-\mathrm{IG} \\
\left(200^{\circ} \mathrm{C}\right)\end{array}$ & ND & $0.294 \pm 0.032^{C}$ & ND & $0.083 \pm 0.009^{\text {в }}$ & ND & $0.377 \pm 0.039^{\mathrm{C}}$ \\
\hline $\begin{array}{c}\text { IG (8 min)-microwave (500 w } 10 \mathrm{~s})-\mathrm{IG} \\
\left(200^{\circ} \mathrm{C}\right)\end{array}$ & ND & $0.462 \pm 0.081^{\mathrm{AB}}$ & ND & $0.139 \pm 0.013^{\mathrm{A}}$ & ND & $0.601 \pm 0.092^{\mathrm{AB}}$ \\
\hline $\begin{array}{c}\text { IG (8 min)-microwave (500 w } 30 \mathrm{~s})-\mathrm{IG} \\
\left(200^{\circ} \mathrm{C}\right)\end{array}$ & ND & $0.443 \pm 0.051^{\text {В }}$ & ND & $0.119 \pm 0.016^{\mathrm{AB}}$ & ND & $0.563 \pm 0.063^{\text {В }}$ \\
\hline $\begin{array}{c}\text { IG (8 min)-microwave (500 w } 60 \mathrm{~s})-\mathrm{IG} \\
\left(200^{\circ} \mathrm{C}\right)\end{array}$ & ND & $0.325 \pm 0.020^{\mathrm{C}}$ & ND & $0.126 \pm 0.024^{\mathrm{A}}$ & ND & $0.451 \pm 0.042^{\mathrm{C}}$ \\
\hline $\begin{array}{c}\text { IG (8 min)-microwave }(1000 \mathrm{w} 10 \mathrm{~s}) \text {-SHS } \\
(4 \mathrm{~min})-\mathrm{IG}\left(200^{\circ} \mathrm{C}\right)\end{array}$ & ND & $0.387 \pm 0.047^{z}$ & ND & $0.114 \pm 0.027^{\mathrm{y}}$ & ND & $0.501 \pm 0.074^{\mathrm{y}}$ \\
\hline $\begin{array}{c}\text { IG (8 min)-microwave }(500 \mathrm{w} 10 \mathrm{~s}) \text {-SHS } \\
\left(4 \text { min)-IG }\left(200^{\circ} \mathrm{C}\right)\right.\end{array}$ & ND & $0.383 \pm 0.090^{z}$ & ND & $0.084 \pm 0.003 y$ & ND & $0.467 \pm 0.089 \mathrm{yz}$ \\
\hline $\begin{array}{c}\text { IG (8 min)-microwave }(500 \mathrm{w} 30 \mathrm{~s}) \text {-SHS } \\
(4 \mathrm{~min})-\mathrm{IG}\left(200^{\circ} \mathrm{C}\right)\end{array}$ & ND & $0.538 \pm 0.004^{y}$ & ND & $0.120 \pm 0.006^{x}$ & ND & $0.658 \pm 0.010^{x}$ \\
\hline $\begin{array}{c}\text { IG (8 min)-microwave }(500 \mathrm{w} 60 \mathrm{~s}) \text {-SHS } \\
(4 \mathrm{~min})-\mathrm{IG}\left(200^{\circ} \mathrm{C}\right)\end{array}$ & ND & $0.413 \pm 0.048^{z}$ & ND & $0.114 \pm 0.082^{x}$ & ND & $0.527 \pm 0.054^{\mathrm{y}}$ \\
\hline
\end{tabular}

Mean \pm SD, standard deviation. "CG" means charcoal grilling, "IG" means infrared grilling, and "SHS" means superheated steam roasting. The different letters a-d represent a significant difference between the content of HAs of "IG" and "IG-SHS-IG" grilled patties at $p<0.05$. The different letters A-C represent a significant difference between the content of HAs of "IG $\left(200{ }^{\circ} \mathrm{C}\right)^{\prime \prime}$ and "IG-microwave-IG (200 $\left.{ }^{\circ} \mathrm{C}\right)$ " grilled patties at $p<0.05$. The different letters $\mathrm{x}-\mathrm{z}$ represent a significant difference between the content of $\mathrm{HAs}$ of "IG (200 $\left.{ }^{\circ} \mathrm{C}\right)^{\prime \prime}$ and "IG-microwave-SHS- IG $\left(200^{\circ} \mathrm{C}\right)$ " grilled patties at $p<0.05$. ND means the content is lower than the detection limit.

\subsection{Effects of Different Thermal Processes on the Moisture Content in Grilled Beef Patties}

The effect of different thermal processes on the moisture content in grilled beef patties is shown in Figure 1.

The moisture content of raw meat was $75.03 \%$. Among the 21 cooking methods, the lowest moisture loss was $13.11 \%$ (IG (8 min)-SHS (5 min)-IG $\left(220^{\circ} \mathrm{C}\right)$ ) and the highest was $25.12 \%$ (IG (8 min)-microwave (1000 w $10 \mathrm{~s})-\mathrm{IG}\left(200^{\circ} \mathrm{C}\right)$ ).

IG-SHS-IG patties had higher moisture content than samples grilled by other methods. As a new type of drying technology, SHS can take away the moisture in the food; however, due to the small drying stress, it can retain some moisture [24]. Drying stress is an important parameter to maintain product quality during the drying process. Too much drying stress will cause the product to lose too much water and cause dry cracking [25].

Compared with IG $\left(220^{\circ} \mathrm{C}\right)$ patties, the moisture content of IG-microwave-IG $\left(200^{\circ} \mathrm{C}\right)$ patties were significantly $(p<0.05)$ reduced, and the moisture content decreased with the extension of the microwave time from $59.98 \%$ to $59.13 \%$. Additionally, the moisture content of IG-microwave-SHS (4 min)-IG $\left(200{ }^{\circ} \mathrm{C}\right)$ patties was decreased compared to IG-SHS ( $4 \mathrm{~min})-\mathrm{IG}\left(200^{\circ} \mathrm{C}\right)$ patties, indicating that the influence of microwave on the moisture of patties is greater than that of SHS. 

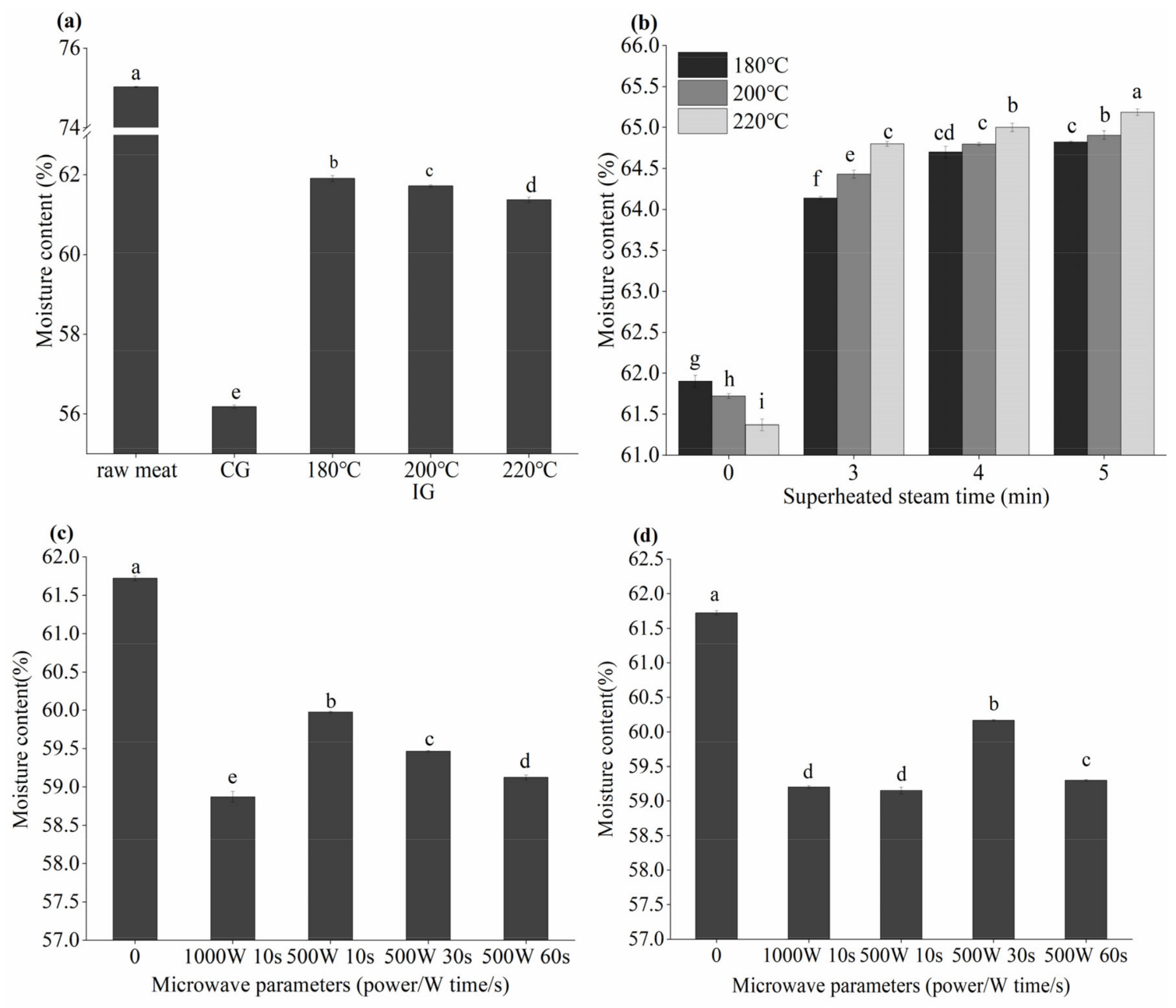

Figure 1. Moisture content in beef patties with different thermal processes. "CG" means charcoal grilling, "IG" means infrared grilling, and "SHS" means superheated steam roasting. (a) CG and IG (180, 200, $\left.220^{\circ} \mathrm{C}\right)$; (b) IG and IG-SHS-IG, the abscissa " 0 " represents IG; (c) IG $\left(200{ }^{\circ} \mathrm{C}\right)$ and IG-microwave-IG $\left(20{ }^{\circ} \mathrm{C}\right)$, the abscissa “ 0 " represents IG $\left(200{ }^{\circ} \mathrm{C}\right)$; (d) IG -SHS (4 min)-IG $\left(200^{\circ} \mathrm{C}\right)$ and IG-microwave-SHS (4 min)-IG $\left(200^{\circ} \mathrm{C}\right)$, the abscissa " 0 ” represents IG-SHS $(4 \mathrm{~min})-\mathrm{IG}\left(200{ }^{\circ} \mathrm{C}\right)$. Different small letters indicate significant difference $p<0.05$ between different cooking methods.

\subsection{Effects of Different Thermal Processes on the TBA Value in Grilled Beef Patties}

The effect of different thermal processes on the TBA value in grilled beef patties is shown in Figure 2.

Lipid oxidation in meat products is usually evaluated according to the TBA value, using the method for the determination of 2-thiobarbituric acid reactive substances [26]. The TBA value of cooked patties was risen, except for CG patties. For CG, the higher temperature and the direct contact with patties may cause the lipid oxidation products to react with other molecules such as amino acids, reducing the amount of oxidation products such as malondialdehyde (MDA) [27]. For IG, the TBA value increased by about 1 time. As the grilling temperature increased, the content of MDA was risen.

The TBA value of IG-SHS-IG patties was decreased. The TBA value of IG-SHS (5 min)IG $\left(180^{\circ} \mathrm{C}\right)$ patties was $0.45 \mathrm{mg} \mathrm{MDA} / \mathrm{Kg}$; at this time, the lipid oxidation degree of patties was the lowest. Studies have shown that SHS causes food to produce fewer free radicals and can reduce lipid oxidation in food [28]. A study by Wang et al. [29] showed that superheated steam makes the content of oxidation products (e.g., aldehydes) significantly lower compared to hot air drying. 

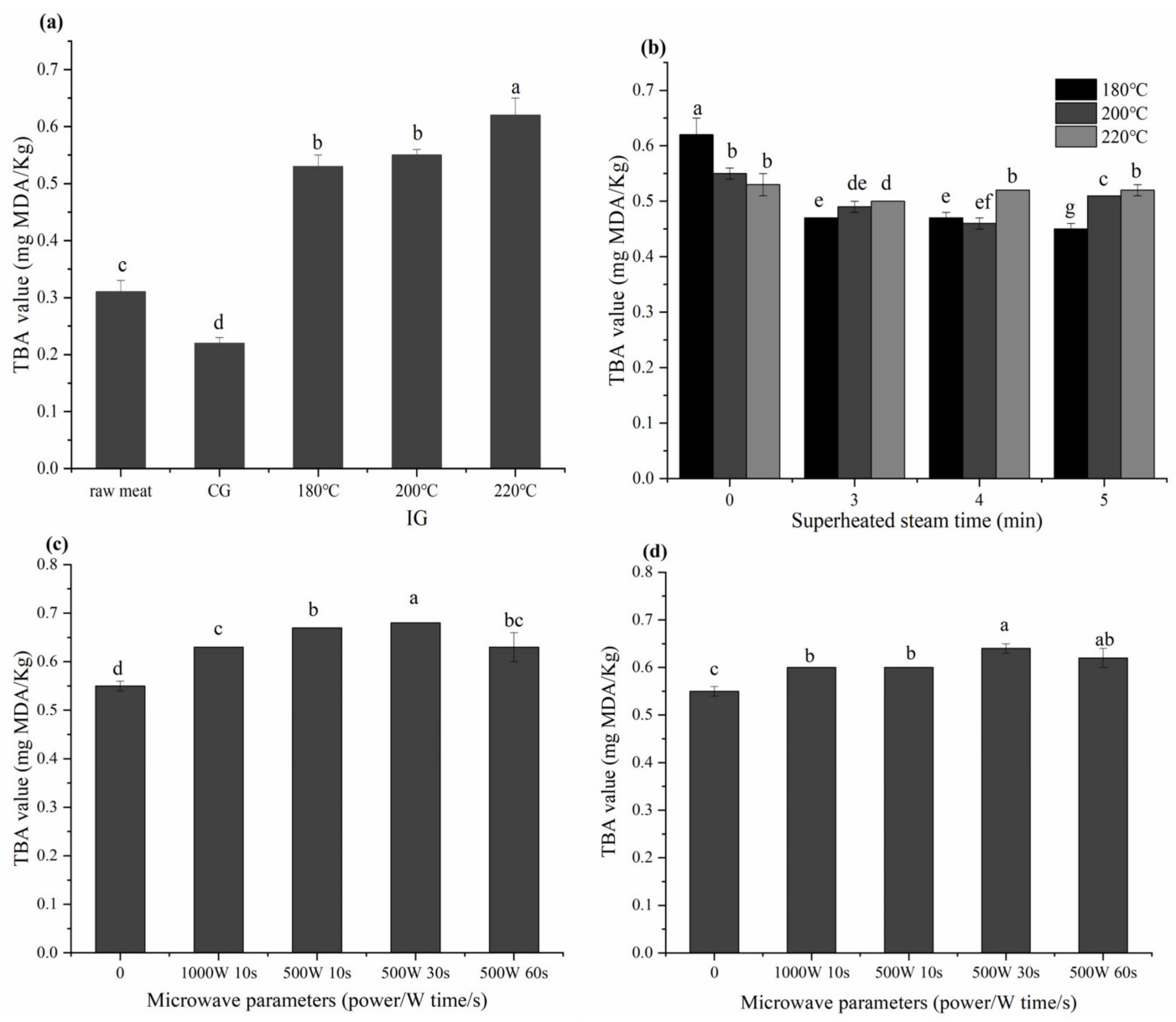

Figure 2. TBA values in beef patties with different thermal processes. "CG" means charcoal grilling, "IG" means infrared grilling and "SHS" means superheated steam roasting. (a) CG and IG (180, 200, $220^{\circ} \mathrm{C}$ ); (b) IG and IG-SHS-IG, the abscissa " 0 " represents IG; (c) IG $\left(200{ }^{\circ} \mathrm{C}\right)$ and IG-microwave-IG $\left(200{ }^{\circ} \mathrm{C}\right)$, the abscissa " 0 " represents IG $\left(200{ }^{\circ} \mathrm{C}\right)$; (d) IG-SHS (4 min)-IG $\left(200^{\circ} \mathrm{C}\right)$ and IG-microwave-SHS $(4 \mathrm{~min})$-IG $\left(200^{\circ} \mathrm{C}\right)$, the abscissa" 0 " represents IG-SHS $(4 \mathrm{~min})-\mathrm{IG}\left(200{ }^{\circ} \mathrm{C}\right)$. Different small letters indicate the significant difference $p<0.05$ between different cooking methods.

The TBA value of IG-microwave-IG patties was decreased. For IG-microwave $(500 \mathrm{w}$ $30 \mathrm{~s})-\mathrm{IG}\left(20{ }^{\circ} \mathrm{C}\right)$, the TBA value of patties is $0.68 \mathrm{mg} \mathrm{MDA} / \mathrm{Kg}$, which is about 1.3 times higher than that of raw meat. Rababah et al. [30] found that the TBA value of microwavecooked lamb was higher than that of lamb cooked in a traditional electric oven. Similarly, Weber et al. [31] believe that the degree of oxidation in microwave samples is higher than that in oven-grilled samples. Certain interactions between microwave and meat lipid lead to the accelerated oxidation of polyunsaturated fatty acids, increasing the secondary oxidation products derived from these fatty acids $[32,33]$.

\subsection{Correlation Analysis and Regression Analysis of HAs with TBA Value and Moisture Content of Grilled Beef Patties}

The Pearson coefficients between hazards and TBA values, as well as the moisture content in patties grilled combined with microwaves or SHS, are shown in Table 5. Linear regression lines between total HAs, TBA values and moisture content in grilled patties, combined with microwaves or SHS, are shown in Figure 3. 
Table 5. The correlation coefficients between hazards and TBA values, moisture content in patties grilled combined with microwaves or SHS (superheated steam roasting). * means $p<0.05$, ** means $p<0.01$.

\begin{tabular}{cccc}
\hline Techniques & Types of HAs & TBA Value & Moisture Content \\
\hline Microwave & Norharman & 0.408 & $0.936^{* *}$ \\
& Harman & 0.541 & 0.651 \\
SHS & Norharman & $0.934^{* *}$ & 0.624 \\
& Harman & $0.754^{*}$ & 0.597 \\
\hline
\end{tabular}
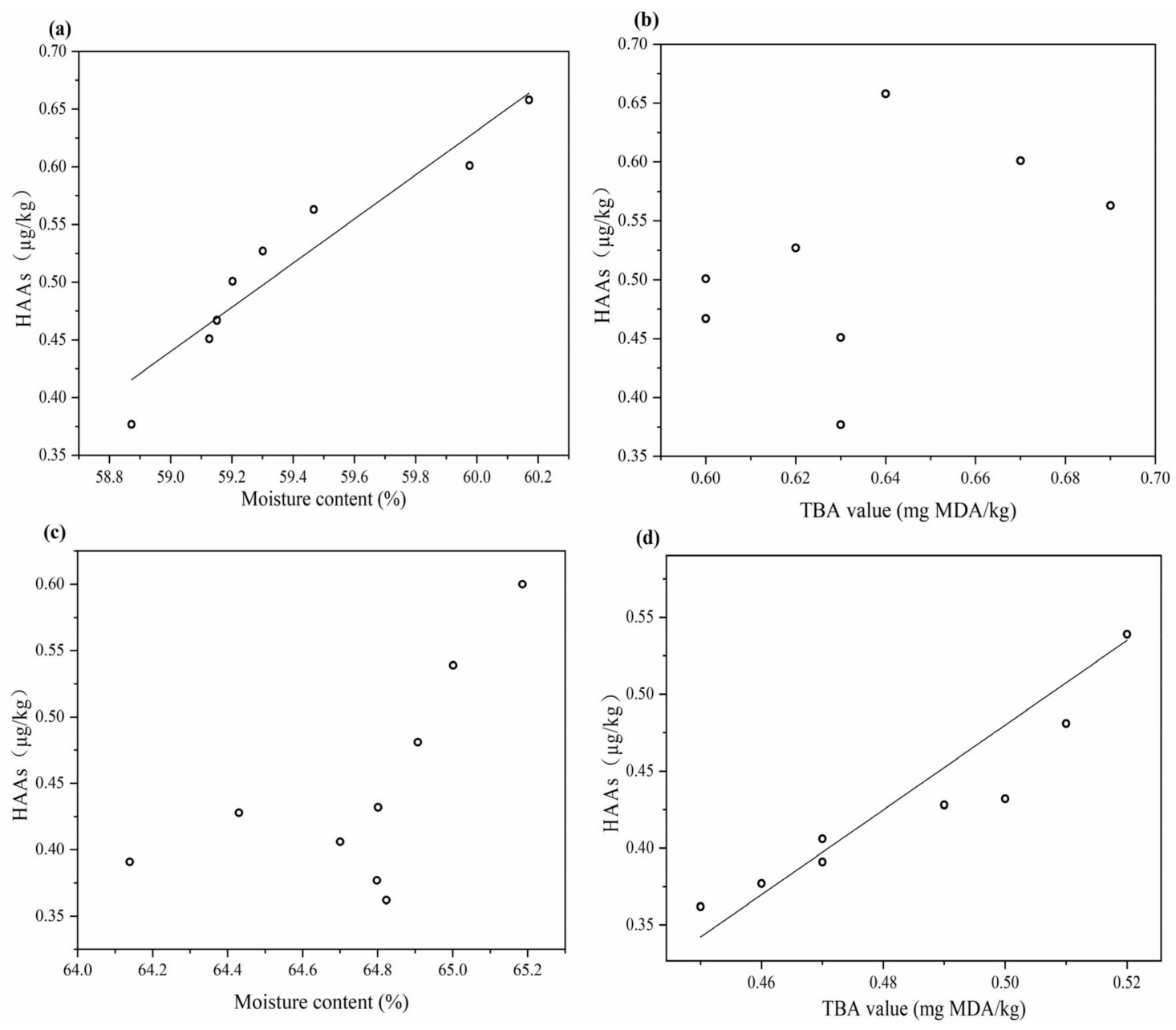

Figure 3. Linear regression lines between total HAs, TBA value and moisture content in patties grilled combined with microwave or SHS (superheated steam roasting). Microwave: (a,b), SHS: (c,d).

The Norharman produced in patties grilled combined with microwave was significantly positively correlated to the moisture content $(0.936, p<0.01)$. Regression analysis showed that the total amount of HAs of cooked patties subjected to microwaving increased linearly with the moisture content of the patties. For microwaving, moisture plays a major role in the formation of HAs. Persson et al. [34] believes that water is the reaction and transmission medium in the heating process for meat products. Water can transport precursor substances to the surface of the patties. On the surface, these substances are exposed to higher levels, and conducive to the formation of HAs at high temperatures. Persson et al. [35] added a mixture of tripolyphosphate and sodium chloride to minced meat to improve water retention, and Shin et al. [36] added carbohydrates to minced meat to bound water, resulting in reduced HAs formation. The key to heating food with electromagnetic waves (e.g., microwave and infrared radiation) lies in matching the wavelength and the 
energy level of the molecules in the food. Due to the different frequencies of infrared radiation and microwave, the frequency at which the object molecules resonate is also different. The frequency of household microwaves is $2450 \mathrm{MHz}$, closer to the vibration frequency of water molecules $(2500 \mathrm{MHz})$ in food. Therefore, the natural frequency of microwave is more suitable for the high-frequency vibration of water molecules in food, which make it difficult for water molecules to transfer from the inside to the surface of the patties, so precursors of HAs will not easily transfer to the surface of the patties. Furthermore, the consumption of water molecules results in a higher droplet volume in the patties; that is, the precursors drip into the oven with the moisture easily during the heating process, resulting in lower HAs, as confirmed by Soladoye et al. [37]. In addition, the microwave wavelength is shorter than infrared and it is not easy to diffract. Therefore, the penetration ability is stronger than infrared radiation. Infrared can only heat the food surface, while the microwave can penetrate several centimeters to generate heat inside the food and avoid local overheating on the food surface, which inhibits the production of HAs.

For SHS, lipid oxidation plays a major role in the formation of HAs. The TBA value was significantly positively correlated to the Norharman $(0.934, p<0.01)$ and Harman $(0.754, p<0.05)$ produced in the patties grilled combined with SHS. Regression analysis showed that the total HA amount for patties grilled combined with SHS increased linearly with the TBA value of the patties. Studies have shown that the free radicals and intermediates produced by lipid oxidation significantly promote the formation of HAs [38-41]. Johansson et al. [42] used antioxidants such as tocopherol to inhibit lipid oxidation and the formation of HAs. Zamora et al. [43] found that the formation level of HAs doubled by adding iron ions to the model system due to the iron-catalyzed lipid peroxidation and the formation of free radicals. In our study, SHS can reduce the formation of HAs by reducing the degree of lipid oxidation in patties. Similarly, Kondjoyan et al. [44] believed that the absence of oxygen during SHS would minimize the degree of lipid oxidation, while reducing the level of HAs detected in beef slices. The intermediate product produced by the reaction of tryptophan with acetaldehyde and formaldehyde undergoes a Pictet-Spengle reaction to form a closed ring, and then the intermediates undergo multiple oxidations to produce Norharman and Harman [45]. The free radicals and oxidation products produced by lipid oxidation may participate in the oxidation process and promote the formation of Norharman and Harman. This mechanism needs to be further explored.

\subsection{Effects of Different Thermal Processes on Quality Characteristics in Grilled Beef Patties}

\subsubsection{Effects of Different Thermal Processes on the Color of Grilled Beef Patties}

The effect of different thermal processes on the color in grilled beef patties are shown in Figure $4 . \mathrm{L}^{*}, \mathrm{a}^{*}$ and $\mathrm{b}^{*}$ represent brightness, redness and yellowness values, respectively. A higher degree of myofibril changes and sarcoplasmic protein aggregation can increase the degree of light scattering and the $L^{*}$ value of patties. Maillard reaction can produce melanoid pigment substances, resulting in a decrease in the $\mathrm{L}^{*}$ value and an increase in the $b^{*}$ value [29]. In our study, the color of charcoal grilled patties was difficult to control and reached the late heating stage quickly, creating the lower $L^{*}$ value. The $a^{*}$ value of patties is related to the conversion between myoglobin, oxymyoglobin and metmyoglobin. The $a^{*}$ value of charcoal grilled patties was higher than that of patties grilled in the oven, because the patties were exposed to sufficient oxygen to accelerate the production of bright red oxymyoglobin in the patties. Because the higher ambient temperature accelerated the Maillard reaction and increased the browning of the patties, the $b^{*}$ value of the charcoal grilled patties was higher than that of the patties cooked in the oven. 

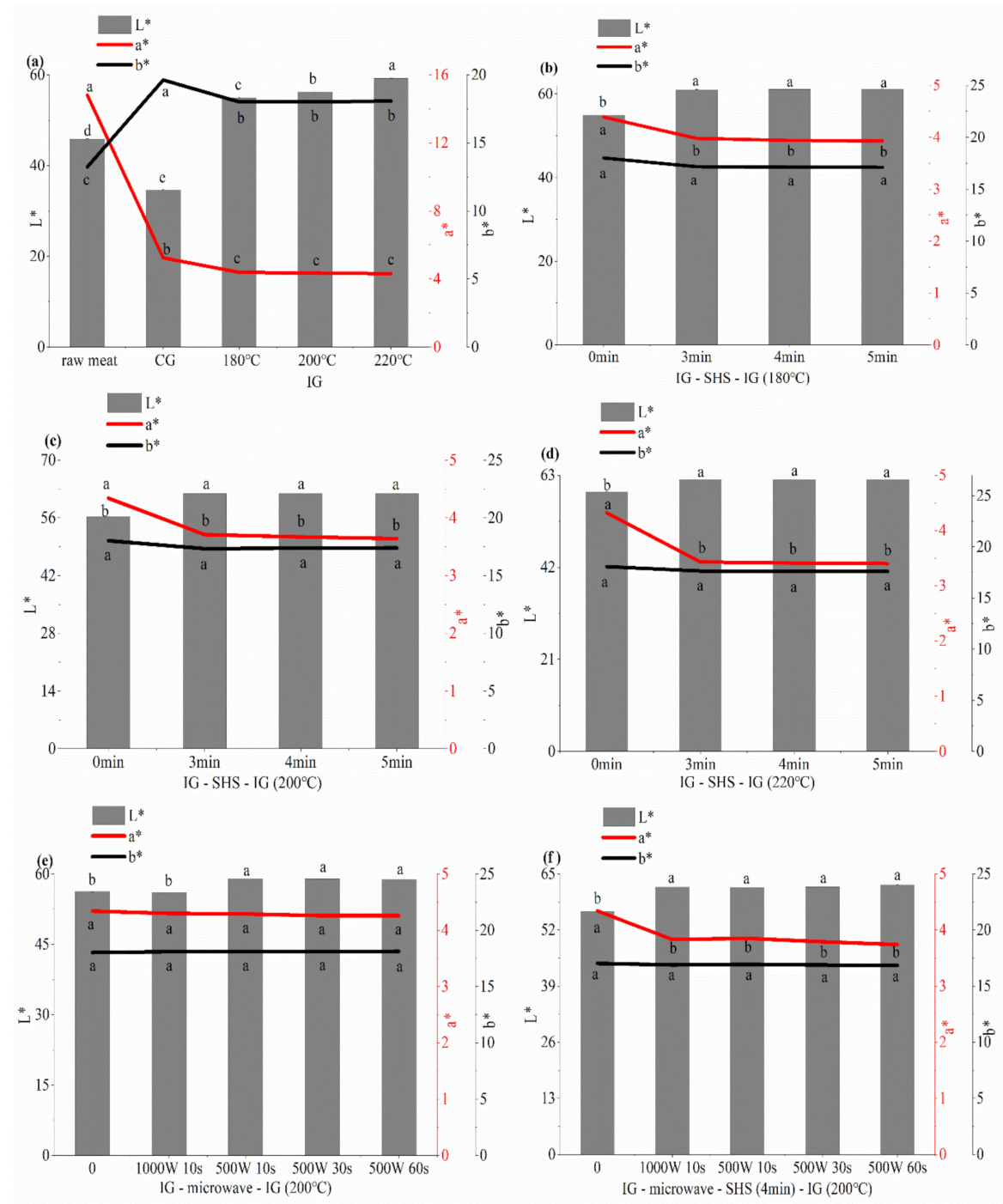

Figure 4. The effect of different thermal processes on the color in grilled beef patties. "CG" means charcoal grilling, "IG" means infrared grilling, and "SHS" means superheated steam roasting. (a) CG and IG $\left(180,200,220^{\circ} \mathrm{C}\right)$; (b) IG $\left(180^{\circ} \mathrm{C}\right)$ and IG-SHS-IG $\left(180^{\circ} \mathrm{C}\right)$, the abscissa " 0 " represents IG $\left(180{ }^{\circ} \mathrm{C}\right)$; (c) IG $\left(200^{\circ} \mathrm{C}\right)$ and IG-SHS-IG $\left(200{ }^{\circ} \mathrm{C}\right)$, the abscissa " 0 " represents IG $\left(200^{\circ} \mathrm{C}\right)$; (d) IG $\left(220^{\circ} \mathrm{C}\right)$ and IG-SHS-IG $\left(220^{\circ} \mathrm{C}\right)$, the abscissa " 0 " represents IG $\left(220^{\circ} \mathrm{C}\right)$; (e) IG $\left(200{ }^{\circ} \mathrm{C}\right)$ and IGmicrowave-IG $\left(200^{\circ} \mathrm{C}\right)$, the abscissa “ 0 ” represents IG $\left(200^{\circ} \mathrm{C}\right)(\mathbf{f}) \mathrm{IG}-\mathrm{SHS}(4 \mathrm{~min})-\mathrm{IG}\left(200^{\circ} \mathrm{C}\right)$ and IG-microwave-SHS (4 min)-IG $\left(200{ }^{\circ} \mathrm{C}\right)$, the abscissa “ 0 ” represents IG-SHS $(4 \mathrm{~min})$-IG $\left(200{ }^{\circ} \mathrm{C}\right)$. Different small letters indicate significant difference $p<0.05$ between different cooking methods.

Due to the higher humidity in the oven and the increase of the moisture content on the surface of IG-SHS-IG patties, the rate of oxidation of myoglobin to oxygenated myoglobin was slowed down and the degree of light scattering on the surface of the patties was increased. IG-SHS-IG patties had a higher $\mathrm{L}^{*}$ value and lower $\mathrm{a}^{*}$ values than by IG patties, but the variation in amplitudes was small. Compared with IG $\left(20{ }^{\circ} \mathrm{C}\right)$ patties, the addition of $500 \mathrm{~W}$ power microwave slightly increased the $\mathrm{L}^{*}$ value of patties, but there is no significant difference between the $\mathrm{a}^{*}$ and $\mathrm{b}^{*}$ values $(p>0.05)$. The addition of a $1000 \mathrm{~W}$ power microwave did not change the color of infrared grilled patties. In addition, the microwave times had no effect on the color difference of infrared grilled patties. Adding a microwave to IG will better maintain the color of the infrared grilled patties. The combined thermal processes selected in this study did not visibly influence the color of grilled patties. 


\subsubsection{Effects of Different Thermal Processes on the Texture of Grilled Beef Patties}

The effect of different thermal processes on the texture in grilled beef patties was shown in Table 6. Different heat transfer methods lead to different heat penetration rates, which affects the formation rate of myofibril protein gel [46]. The hardness of charcoal grilled patties was much greater than with other cooking methods. The hardness, springiness and chewiness of the infrared grilled patties increased with an increasing cooking temperature $(p<0.05)$. According to our research, CG is not conducive to controlling the texture of the patties, while IG can control the texture of the patties by controlling the grilling temperature, which makes the operation more flexible. For the combined thermal processes, the SHS conditions can better maintain the grilled texture of the patties than microwave heating. Although the hardness, springiness and chewiness of IG-SHS-IG patties were increased at all the cooking intervals, this change was slight, from 4969.90 (the hardness value of IG $\left(200^{\circ} \mathrm{C}\right)$ ) to 5061.81 (the hardness value of IG-SHS $(4 \mathrm{~min})$-IG $\left(200^{\circ} \mathrm{C}\right)$ ). For microwave, the hardness value was from 4969.90 (IG $\left(200^{\circ} \mathrm{C}\right)$ ) to 5289.27 (IG-microwave $\left.(500 \mathrm{w} 10 \mathrm{~s})-\mathrm{IG}\left(200^{\circ} \mathrm{C}\right)\right)$. A change of less than an order of magnitude will not affect the grilled texture of the patties, nor will it affect consumer acceptance.

Table 6. Effects of different thermal processes on the texture in grilled beef patties.

\begin{tabular}{|c|c|c|c|c|c|c|}
\hline \multirow{2}{*}{ Cooking Process } & \multicolumn{6}{|c|}{ Parameter } \\
\hline & Hardness & Springiness & Cohesiveness & Gumminess & Chewiness & Resilience \\
\hline CG & $6766.43 \pm 18.92$ & $0.909 \pm 0.02$ & $0.832 \pm 0.00$ & $5629.67 \pm 21.85$ & $5117.37 \pm 18.21$ & $0.417 \pm 0.01$ \\
\hline IG $\left(180^{\circ} \mathrm{C}\right)$ & $4682.62 \pm 28.39 \mathrm{~g}$ & $0.81 \pm 0.00^{\mathrm{e}}$ & $0.91 \pm 0.02^{b}$ & $4261.18 \pm 21.46^{\mathrm{d}}$ & $3451.56 \pm 19.87^{\mathrm{i}}$ & $0.37 \pm 0.01 \mathrm{bc}$ \\
\hline IG $\left(200^{\circ} \mathrm{C}\right)$ & $4969.90 \pm 28.37 \mathrm{dDz}$ & $0.93 \pm 0.02 \mathrm{dAz}$ & $0.87 \pm 0.04^{\mathrm{cBx}}$ & $4323.81 \pm 28.37 \mathrm{cDz}$ & $4021.14 \pm 20.81 \mathrm{eEz}$ & $0.40 \pm 0.01$ abAx \\
\hline IG $\left(220^{\circ} \mathrm{C}\right)$ & $5217.76 \pm 34.42^{b}$ & $1.00 \pm 0.01 \mathrm{bc}$ & $0.96 \pm 0.01$ a & $5009.05 \pm 15.37^{\mathrm{a}}$ & $5009.05 \pm 18.01$ & $0.40 \pm 0.04 \mathrm{ab}$ \\
\hline IG $(8 \mathrm{~min})-\mathrm{SHS}(3 \mathrm{~min})-\mathrm{IG}\left(180^{\circ} \mathrm{C}\right)$ & $4781.28 \pm 23.91 \mathrm{f}$ & $0.93 \pm 0.01 \mathrm{~d}$ & $0.83 \pm 0.01 \mathrm{~d}$ & $3968.46 \pm 13.24^{\mathrm{f}}$ & $3690.67 \pm 19.82 \mathrm{~g}$ & $0.35 \pm 0.02 \mathrm{~cd}$ \\
\hline IG $(8 \mathrm{~min})-\mathrm{SHS}(3 \mathrm{~min})-\mathrm{IG}\left(200^{\circ} \mathrm{C}\right)$ & $5001.43 \pm 27.18^{d}$ & $0.99 \pm 0.01 \mathrm{bc}$ & $0.83 \pm 0.00 \mathrm{~d}$ & $4151.19 \pm 18.69^{\mathrm{e}}$ & $4109.68 \pm 29.18^{d}$ & $0.41 \pm 0.00^{\mathrm{a}}$ \\
\hline IG (8 min)-SHS $(3 \mathrm{~min})-\mathrm{IG}\left(220^{\circ} \mathrm{C}\right)$ & $5481.71 \pm 17.29 \mathrm{a}$ & $1.03 \pm 0.00^{\mathrm{a}}$ & $0.80 \pm 0.01 \mathrm{e}$ & $4385.37 \pm 13.90^{b}$ & $4516.92 \pm 19.04 \mathrm{~b}$ & $0.43 \pm 0.00^{\mathrm{a}}$ \\
\hline IG $(8 \mathrm{~min})$-SHS $(4 \mathrm{~min})-\mathrm{IG}\left(180^{\circ} \mathrm{C}\right)$ & $4817.45 \pm 27.19^{\mathrm{f}}$ & $0.93 \pm 0.02^{d}$ & $0.78 \pm 0.02$ ef & $3757.61 \pm 28.19^{h}$ & $3494.57 \pm 18.23^{\mathrm{h}}$ & $0.34 \pm 0.01^{\mathrm{cd}}$ \\
\hline IG (8 min)-SHS $(4 \mathrm{~min})-\mathrm{IG}\left(200^{\circ} \mathrm{C}\right)$ & $5061.81 \pm 18.02^{c}$ & $0.98 \pm 0.00^{c}$ & $0.77 \pm 0.00^{\mathrm{f}}$ & $3897.59 \pm 13.91 \mathrm{~g}$ & $3819.64 \pm 17.26^{\mathrm{f}}$ & $0.40 \pm 0.01 \mathrm{ab}$ \\
\hline IG (8 min)-SHS $(4 \mathrm{~min})-\mathrm{IG}\left(220^{\circ} \mathrm{C}\right)$ & $5497.82 \pm 12.93^{\text {a }}$ & $1.01 \pm 0.02 \mathrm{ab}$ & $0.76 \pm 0.01^{\mathrm{f}}$ & $4178.29 \pm 28.16^{\mathrm{e}}$ & $4220.13 \pm 21.16^{c}$ & $0.42 \pm 0.01 \mathrm{a}$ \\
\hline IG $(8 \mathrm{~min})-\mathrm{SHS}(5 \mathrm{~min})-\mathrm{IG}\left(180^{\circ} \mathrm{C}\right)$ & $4908.26 \pm 16.26^{\mathrm{e}}$ & $0.95 \pm 0.00 \mathrm{~d}$ & $0.73 \pm 0.00 \mathrm{~g}$ & $3583.03 \pm 28.19 j$ & $3403.88 \pm 13.02^{j}$ & $0.33 \pm 0.03 \mathrm{~d}$ \\
\hline IG (8 min)-SHS (5 min)-IG $\left(200^{\circ} \mathrm{C}\right)$ & $5082.27 \pm 18.01^{\mathrm{c}}$ & $1.00 \pm 0.03 \mathrm{bc}$ & $0.73 \pm 0.00 \mathrm{~g}$ & $3710.06 \pm 18.21^{\mathrm{i}}$ & $3710.06 \pm 18.27 \mathrm{~g}$ & $0.42 \pm 0.01 \mathrm{a}$ \\
\hline IG $(8 \mathrm{~min})-\mathrm{SHS}(5 \mathrm{~min})-\mathrm{IG}\left(220^{\circ} \mathrm{C}\right)$ & $5513.93 \pm 17.91^{\mathrm{a}}$ & $1.03 \pm 0.01 \mathrm{a}$ & $0.71 \pm 0.01 \mathrm{~g}$ & $3914.89 \pm 12.13 \mathrm{~g}$ & $4032.34 \pm 16.23^{\mathrm{e}}$ & $0.42 \pm 0.00^{\mathrm{a}}$ \\
\hline IG (8 min)-microwave $(1000 \mathrm{w} 10 \mathrm{~s})$-IG $\left(200^{\circ} \mathrm{C}\right)$ & $5312.36 \pm 23.19^{B C}$ & $0.87 \pm 0.01 \mathrm{~B}$ & $0.95 \pm 0.01 \mathrm{~A}$ & $5046.74 \pm 13.87^{\text {B }}$ & $4390.67 \pm 15.59^{B}$ & $0.39 \pm 0.03 \mathrm{~A}$ \\
\hline IG (8 min)-microwave (500 w $10 \mathrm{~s})$-IG $\left(200^{\circ} \mathrm{C}\right)$ & $5289.27 \pm 9.25 \mathrm{C}$ & $0.93 \pm 0.00 \mathrm{~A}$ & $0.96 \pm 0.00 \mathrm{~A}$ & $5077.70 \pm 14.65 \mathrm{AB}$ & $4722.26 \pm 15.87 \mathrm{~A}$ & $0.40 \pm 0.03 \mathrm{~A}$ \\
\hline IG $(8 \mathrm{~min})$-microwave $(500 \mathrm{w} 20 \mathrm{~s})-\mathrm{IG}\left(200^{\circ} \mathrm{C}\right)$ & $5330.23 \pm 10.23$ B & $0.86 \pm 0.00^{B}$ & $0.94 \pm 0.03 \mathrm{~A}$ & $5010.42 \pm 13.86^{\mathrm{C}}$ & $4308.96 \pm 24.54 \mathrm{C}$ & $0.38 \pm 0.01 \mathrm{~A}$ \\
\hline IG $(8 \mathrm{~min})$-microwave $(500 \mathrm{w} 30 \mathrm{~s})-\mathrm{IG}\left(200^{\circ} \mathrm{C}\right)$ & $5429.26 \pm 18.29 \mathrm{~A}$ & $0.83 \pm 0.01 \mathrm{C}$ & $0.94 \pm 0.02 \mathrm{~A}$ & $5103.50 \pm 12.87^{\mathrm{A}}$ & $4235.91 \pm 14.53^{\mathrm{D}}$ & $0.41 \pm 0.03^{\mathrm{A}}$ \\
\hline $\begin{array}{l}\text { IG (8 min)-microwave (1000 w } 10 \text { s)-SHS } \\
\text { (4 min)-IG }\left(200^{\circ} \mathrm{C}\right)\end{array}$ & $5419.32 \pm 17.28^{y}$ & $0.97 \pm 0.011^{y}$ & $0.68 \pm 0.01^{z}$ & $4446.74 \pm 13.94{ }^{y}$ & $4390.67 \pm 23.98^{y}$ & $0.34 \pm 0.01 \mathrm{y}$ \\
\hline $\begin{array}{c}\text { IG (8 min)-microwave }(500 \mathrm{w} 10 \mathrm{~s}) \text {-SHS } \\
(4 \mathrm{~min}) \text {-IG }\left(200^{\circ} \mathrm{C}\right)\end{array}$ & $5137.29 \pm 16.39^{z}$ & $0.95 \pm 0.00^{\mathrm{z}}$ & $0.69 \pm 0.01^{z}$ & $4577.70 \pm 12.75^{\mathrm{x}}$ & $4722.26 \pm 34.72^{x}$ & $0.31 \pm 0.02^{z}$ \\
\hline $\begin{array}{c}\text { IG (8 min)-microwave (500 } \mathrm{W} 20 \mathrm{~s}) \text {-SHS } \\
\left(4 \text { min)-IG }\left(200^{\circ} \mathrm{C}\right)\right.\end{array}$ & $5440.23 \pm 12.38^{y}$ & $0.96 \pm 0.00 \mathrm{yz}$ & $0.72 \pm 0.02 \mathrm{y}$ & $4360.42 \pm 17.92^{z}$ & $4308.96 \pm 29.64^{y}$ & $0.34 \pm 0.02 \mathrm{y}$ \\
\hline $\begin{array}{c}\text { IG (8 min)-microwave (500 w } 30 \mathrm{~s}) \text {-SHS } \\
\left(4 \text { min)-IG }\left(200^{\circ} \mathrm{C}\right)\right.\end{array}$ & $5567.29 \pm 17.29^{x}$ & $1.01 \pm 0.01^{x}$ & $0.82 \pm 0.01^{x}$ & $4503.50 \pm 18.46^{x}$ & $4235.91 \pm 13.79^{\mathrm{z}}$ & $0.35 \pm 0.00 \mathrm{y}$ \\
\hline
\end{tabular}

Mean \pm SD, standard deviation. "CG" means charcoal grilling, "IG" means infrared grilling, and "SHS" means superheated steam roasting. The different letters a-j represent a significant difference between every texture parameter of "IG" and "IG-SHS-IG" grilled patties at $p<0.05$. The different letters A-E represent a significant difference between every texture parameter of "IG $\left(200^{\circ} \mathrm{C}\right)$ " and "IG-microwave-IG $\left(200^{\circ} \mathrm{C}\right)$ " grilled patties at $p<0.05$. The different letters $\mathrm{x}-\mathrm{z}$ represent a significant difference between every texture parameter of "IG $\left(200^{\circ} \mathrm{C}\right)$ " and "IG-microwave-SHS- IG $\left(200^{\circ} \mathrm{C}\right)^{\prime \prime}$ grilled patties at $p<0.05$.

\section{Conclusions}

Of all the thermal processes involved in this research, the greatest moisture loss, highest values of dark color and highest HA content were observed in charcoal grilled beef patties. Compared with CG, AIA-type heterocyclic amines obtained by other thermal processes in the oven are easily degraded due to the prolonged grilling time. IG combined with microwave or SHS, as well as the successive use of three technologies, effectively decreased the content of HAs. Additionally, the combination of thermal processes can ensure the grilled quality of beef patties, and the combined use of SHS technology has a lesser impact on the texture of the patties compared to the combined use of microwave technology. Regarding color, the yellowness value of the patties grilled by the combined thermal processes did not change compared with the patties grilled by IG, but the brightness value of the patties is easily affected by the combined grilling processes. The combined use of microwave technology and IG has a lesser impact on the color of the patties compared with the combined use of SHS and IG. It is difficult for people to visually distinguish this slight color change. In addition, compared with IG, the microwave consumes more 
moisture and accelerates the lipid oxidation of patties, but SHS can better retain the moisture of patties better and reduce the degree of lipid oxidation in patties. Correlation analysis and regression analysis show that the inhibitory effects of a microwave and SHS on the formation of HAs are related to the moisture content and lipid oxidation of grilled patties, respectively. The above results showed that IG combined with SHS or a microwave could be a superb alternative to maintain the quality profiles and control the HAs of grilled patties, but this mechanism needs to be further explored.

Supplementary Materials: The following are available online at https: / www.mdpi.com/article/10 .3390/foods10071490/s1, Table S1: The LOQs, LODs and recovery \% of UPLC-MS/MS, Table S2: The cooking time of 21 thermal processes.

Author Contributions: Conceptualization, S.W. and H.Y.; methodology, W.W. and L.D.; formal analysis, W.W. and L.D.; data curation, W.W.; writing-original draft preparation, W.W.; writingreview and editing, W.W. and Y.Z.; supervision, L.D.; project administration, S.W. and H.Y.; funding acquisition, S.W. All authors have read and agreed to the published version of the manuscript.

Funding: This research was funded by National Key R\&D Program of China (2017 YFC1600402).

Acknowledgments: The authors are grateful to Fan Wei and Zhenting Yu for assisting with the experiments.

Conflicts of Interest: The authors declare no conflict of interest.

\section{References}

1. Barzegar, F.; Kamankesh, M.; Mohammadi, A. Heterocyclic aromatic amines in cooked food: A review on formation, health risk-toxicology and their analytical techniques. Food Chem. 2019, 280, 240-254. [CrossRef]

2. Koszucka, A.; Nowak, A. Thermal processing food-related toxicants: A review. Crit. Rev. Food Sci. Nutr. 2019, 59, 3579-3596. [CrossRef]

3. Gibis, M.; Loeffler, M. Effect of Creatine and Glucose on Formation of Heterocyclic Amines in Grilled Chicken Breasts. Foods 2019, 8, 616. [CrossRef]

4. Gibis, M.; Weiss, J. Antioxidant capacity and inhibitory effect of grape seed and rosemary extract in marinades on the formation of heterocyclic amines in fried beef patties. Food Chem. 2012, 134, 766-774. [CrossRef]

5. Zeng, M.; He, Z.; Zheng, Z.; Qin, F.; Tao, G. Effect of six Chinese spices on heterocyclic amine profiles in roast beef patties by ultraperformance liquid chromatography- tandem mass spectrometry and principal component analysis. J. Agric. Food Chem. 2014, 62, 9908-9915. [CrossRef]

6. Chen, J.; He, Z.; Qin, F.; Chen, J.; Cao, D. Inhibitory profiles of spices against free and protein-bound heterocyclic amines of roast beef patties as revealed by ultraperformance liquid chromatography-tandem mass spectrometry and principal component analysis. Food Funct. 2017, 8, 3938-3950. [CrossRef] [PubMed]

7. Viegas, O.; Novo, P.; Pinto, E.; Pinho, O.; Ferreira, I.M.P.L.V.O. Effect of charcoal types and grilling conditions on formation of heterocyclic aromatic amines (HAs) and polycyclic aromatic hydrocarbons (PAHs) in grilled muscle foods. Food Chem. Toxicol. 2012, 50, 2128-2134. [CrossRef] [PubMed]

8. Rastogi, N.K. Recent Trends and Developments in Infrared Heating in Food Processing. Crit. Rev. Food Sci. Nutr. 2012, 52, 737-760. [CrossRef] [PubMed]

9. Haskaraca, G.; Demirok, E.; Kolsarici, N.; Oz, F.; Ozsarac, N. Effect of green tea extract and microwave pre-cooking on the formation of heterocyclic aromatic amines in fried chicken meat products. Food Res. Int. 2014, 63, 373-381. [CrossRef]

10. Somjai, T.; Achariyaviriya, S.; Achariyaviriya, A.; Namsanguan, K. Strategy for longan drying in two-stage superheated steam and hot air. J. Food Eng. 2009, 95, 313-321. [CrossRef]

11. Raza, A.; Shabbir, M.A.; Khan, M.I. Effect of Thermal Treatments on the Formation of Heterocyclic Aromatic Amines in Various Meats. J. Food Process. Preserv. 2015, 39, 376-383. [CrossRef]

12. Omojola, A.B.; Ahmed, S.A.; Attoh-Kotoku, V. Effect of cooking methods on cholesterol, mineral composition and formation of total heterocyclic aromatic amines in Muscovy drake meat. J. Sci. Food Agric. 2015, 95, 98-102. [CrossRef] [PubMed]

13. Oz, F.; Kaban, G.; Kaya, M. Effects of Cooking Techniques and Levels on the Formation of Heterocyclic Aromatic Amines in Chicken and Fish. J. Anim. Vet. Adv. 2010, 9, 1259-1264. [CrossRef]

14. Jinap, S.; Mohd-Mokhtar, M.S.; Farhadian, A. Effects of varying degrees of doneness on the formation of Heterocyclic Aromatic Amines in chicken and beef satay. Meat Sci. 2013, 94, 202-207. [CrossRef]

15. Jung, K.H.; Shin, H.S. Influence of Microwave Pretreatment on the Formation of Heterocyclic Amines in Fried Beef Patties. Korean J. Food Sci. Anim. Resour. 2009, 29, 719-725. [CrossRef]

16. Chiu, C.P.; Yang, D.Y.; Chen, B.H. Formation of heterocyclic amines in cooked chicken legs. J. Food Prot. 1998, 61, 712-719. [CrossRef] [PubMed] 
17. Isleroglu, H.; Kemerli, T.; Ozdestan, O. Effect of oven cooking method on formation of heterocyclic amines and quality characteristics of chicken patties: Steam-assisted hybrid oven versus convection ovens. Poult. Sci. 2014, 93, 296-303. [CrossRef] [PubMed]

18. Suleman, R.; Hui, T.; Wang, Z.; Liu, H. Comparative analysis of charcoal grilling, infrared grilling and superheated steam roasting on the colour, textural quality and heterocyclic aromatic amines of lamb patties. Int. J. Food Sci. Technol. 2019, 55, 1057-1068. [CrossRef]

19. Hai, D.; Huang, X.Q.; Song, L.J. Effects of different modified atmosphere treatments on lipid oxidation in spiced beef at different storage temperatures. Food Sci. Nutr. 2021, 9, 1422-1431. [CrossRef] [PubMed]

20. Felton, J.S.; Knize, M.G.; Hatch, F.T.; Tanga, M.J.; Colvin, M.E. Heterocyclic amine formation and the impact of structure on their mutagenicity. Cancer Lett. 1999, 143, 127-134. [CrossRef]

21. Polak, T.; Dosler, D.; Zlender, B.; Gasperlin, L. Heterocyclic amines in aged and thermally treated pork longissimus dorsi muscle of normal and PSE quality. LWT Food Sci. Technol. 2009, 42, 504-513. [CrossRef]

22. Suleman, R.; Wang, Z.; Aadil, R.M.; Hui, T.; Hopkins, D.L.; Zhang, D. Effect of cooking on the nutritive quality, sensory properties and safety of lamb meat: Current challenges and future prospects. Meat Sci. 2020, 167, 108172. [CrossRef] [PubMed]

23. Pathare, P.B.; Roskilly, A.P. Quality and Energy Evaluation in Meat Cooking. Food Eng. Rev. 2016, 8, 435-447. [CrossRef]

24. Oz, F.; Yuzer, M.O. The effects of different cooking methods on the formation of heterocyclic aromatic amines in turkey meat. $J$. Food Process. Preserv. 2017, 41, e13196. [CrossRef]

25. Fu, Z.Y.; Avramidis, S.; Weng, X.; Cai, Y.C.; Zhou, Y.D. Influence mechanism of radio frequency heating on moisture transfer and drying stress in larch boxed-heart square timber. Dry. Technol. 2019, 37, 1625-1632. [CrossRef]

26. Bornez, R.; Linares, M.B.; Vergara, H. Microbial quality and lipid oxidation of Manchega breed suckling lamb meat: Effect of stunning method and modified atmosphere packaging. Meat Sci. 2009, 83, 383-389. [CrossRef]

27. Meinert, L.; Andersen, L.T.; Bredie, W.L.P.; Bjergegaard, C.; Aaslyng, M.D. Chemical and sensory characterisation of pan-fried pork flavour: Interactions between raw meat quality, ageing and frying temperature. Meat Sci. 2007, 75, 229-242. [CrossRef]

28. Kondjoyan, A.; Chevolleau, S.; Greve, E.; Gatellier, P.; Sante-Lhoutellier, V.; Bruel, S.; Touzet, C.; Portanguen, S.; Debrauwer, L. Formation of heterocyclic amines in slices of Longissimus thoracis beef muscle subjected to jets of superheated steam. Food Chem. 2010, 119, 19-26. [CrossRef]

29. Wang, R.; Huang, F.; Zhang, L.; Liu, Q.; Zhang, C.; Zhang, H. Changes in the texture, microstructures, colour and volatile compounds of pork meat loins during superheated steam cooking. Int. J. Food Sci. Technol. 2019, 54, 2821-2830. [CrossRef]

30. Rababah, T.M.; Feng, H.; Yang, W.; Al-Mahasneh, M.; Ereifej, K.; Al-u'datt, M. Effect of Grape Seed Extracts on Physicochemical and Sensory Properties of Goat Meat Cooked by Conventional Electric or Microwave Ovens. Food Sci. Technol. Res. 2012, 18, 325-332. [CrossRef]

31. Weber, J.; Bochi, V.C.; Ribeiro, C.P.; Victorio, A.D.; Emanuelli, T. Effect of different cooking methods on the oxidation, proximate and fatty acid composition of silver catfish (Rhamdiaquelen) fillets. Food Chem. 2008, 106, 140-146. [CrossRef]

32. Broncano, J.M.; Petron, M.J.; Parra, V.; Timon, M.L. Effect of different cooking methods on lipid oxidation and formation of free cholesterol oxidation products (COPs) in Latissimus dorsi muscle of Iberian pigs. Meat Sci. 2009, 83, 431-437. [CrossRef]

33. Hernandez, P.; Navarro, J.L.; Toldra, F. Lipids of pork meat as affected by various cooking techniques. Food Sci. Technol. Int. 1999, 5, 501-508. [CrossRef]

34. Persson, E.; Sjoholm, I.; Skog, K. Heat and mass transfer in chicken breasts-Effect on PhIP formation. Eur. Food Res. Technol. 2002, 214, 455-459.

35. Persson, E.; Sjoholm, I.; Skog, K. Effect of high water-holding capacity on the formation of heterocyclic amines in fried beefburgers. J. Agric. Food Chem. 2003, 51, 4472-4477. [CrossRef]

36. Shin, H.S.; Lee, S. Influence of honey containing marinades on heterocyclic aromatic amine formation and overall mutagenicity in fried pork chops. Food Sci. Biotechnol. 2004, 13, 651-656.

37. Soladoye, O.P.; Shand, P.; Dugan, M.E.R.; Gariepy, C.; Aalhus, J.L.; Estevez, M.; Juarez, M. Influence of cooking methods and storage time on lipid and protein oxidation and heterocyclic aromatic amines production in bacon. Food Res. Int. 2017, 99, 660-669. [CrossRef]

38. Zamora, R.; Alcon, E.; Hidalgo, F.J. Effect of lipid oxidation products on the formation of 2-amino-1-methyl-6-phenylimidazo 4,5-b pyridine (PhIP) in model systems. Food Chem. 2012, 135, 2569-2574. [CrossRef]

39. Zamora, R.; Hidalgo, F.J. 2-Amino-1-methyl-6-phenylimidazo 4,5-b pyridine (PhIP) formation and fate: An example of the coordinate contribution of lipid oxidation and Maillard reaction to the production and elimination of processing-related food toxicants. RSC Adv. 2015, 5, 9709-9721. [CrossRef]

40. Sanz Alaejos, M.; Afonso, A.M. Factors That Affect the Content of Heterocyclic Aromatic Amines in Foods. Compr. Rev. Food Sci. Food Saf. 2011, 10, 52-108. [CrossRef]

41. Wu, X.G.; Zhang, Z.G.; He, Z.Y.; Wang, Z.J.; Qin, F.; Zeng, M.M.; Chen, J. Effect of Freeze-Thaw Cycles on the Oxidation of Protein and Fat and Its Relationship with the Formation of Heterocyclic Aromatic Amines and Advanced Glycation End Products in Raw Meat. Molecules 2021, 26, 1264. [CrossRef] [PubMed]

42. Johansson, M.A.; Fredholm, L.; Bjerne, I.; Jagerstad, M. Influence of frying fat on the formation of heterocyclic amines in fried beefburgers and pan residues. Food Chem. Toxicol. 1995, 33, 993-1004. [CrossRef] 
43. Zamora, R.; Navarro, J.L.; Aguilar, I.; Hidalgo, F.J. Lipid-derived aldehyde degradation under thermal conditions. Food Chem. 2015, 174, 89-96. [CrossRef] [PubMed]

44. Kondjoyan, A.; Chevolleau, S.; Portanguen, S.; Molina, J.; Ikonic, P.; Clerjon, S.; Debrauwer, L. Relation between crust development and heterocyclic aromatic amine formation when air-roasting a meat cylinder. Food Chem. 2016, 213, 641-646. [CrossRef] [PubMed]

45. Chen, X.; Jia, W.; Zhu, L.; Mao, L.; Zhang, Y. Recent advances in heterocyclic aromatic amines: An update on food safety and hazardous control from food processing to dietary intake. Compr. Rev. Food Sci. Food Saf. 2020, 19, 124-148. [CrossRef]

46. Kaur, L.; Maudens, E.; Haisman, D.R.; Boland, M.J.; Singh, H. Microstructure and protein digestibility of beef: The effect of cooking conditions as used in stews and curries. LWT Food Sci. Technol. 2014, 55, 612-620. [CrossRef] 